\section{Master of biological research}

\section{R. Pollock}

Selected Papers in Molecular Biology. By Jacques Monod. Edited by A. Lwoff and A. Ullmann. Pp. 753. (Academic: New York, San Francisco and London, 1978.) $\$ 29.50$; £19.15.

No doubt there will always be some scientists, overburdened by the appalling mass of literature that has to be sifted through these days, to protest against the publication of reports that have already appeared in print and are generally available in libraries. But there must be many more who will warmly welcome this collection of papers by Jacques Monod, who was unquestionably one of the greatest of the architects and exponents of the new biology. It is, in fact, a selection of less than half his total output of 131 scientific papers and, rather unfortunately, does not include any of his forewords, essays, reviews or recorded interviews on broader themes, which are less easy to get hold of than the others. Indeed, there must be many who would have liked an unexpurgated collection of The Complete Works. $\mathrm{He}$ was a master of beautiful and clear writing, both in French and English, and his views on almost everything are worth reading.

Presumably the basis of the editors' selection was to avoid redundancy of material and the extravagance of two volumes. The 62 papers reprinted make a fair-sized book which, priced at over $£ 19$. seems expensive enough for something in principle already available, but still less than half what would have to be paid for loose xerox copies. The volume is generally well produced and only relatively few articles have had to be reduced to an extent where the size of print is borderline for easy reading. A fair proportion of the papers excluded are abbreviated preliminary reports appearing in Comptes rendues..., completed versions of which are published elsewhere; but there are some apparent inconsistencies. An introductory explanation of the selection principles used would in any case have been interesting and reassuring.

The book in itself is a great tribute to the work and genius of Jacques Monod. "Occasionally the career of a scientist", write the editors in their preface, "is marked by an important discovery. It is most unusual that it be illuminated by an uninterrupted series of great discoveries and still more unusual when each discovery gives rise to new concepts and opens new vistas". But it is much more than just a tribute. It is a story, told in the dry, restricted language which research workers are expected to use for recording what they have done and how they think, of one man's contribution to scientific knowledge. And, apart from a very few pieces of work mostly at the beginning of his career, it is the story about a single problem: the specific control of enzyme production in living organisms. This problem orginally presented itself, apparently rather narrowly, as the phenomenon of "enzyme adaptation' in microorganisms and it was tackled by Monod mainly through the

\section{Sorry, for copyright reasons some images on this page may not be available online}

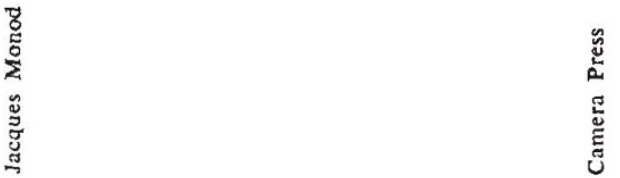

study of a single system: the famous $\beta$-galactosidase of $E$. coli; but it carried with it tremendous implications for a better understanding of the wider problem of the phenotoypic expression of genetic potentiality in general.

But heaven forbid that anyone should read the book like a story from beginning to end! It is, rather, a book of reference and inspiration, to be consulted by research students in order to learn something about how a master of biological research thought and worked, and for historians to understand better thereby the evolution of ideas in one area of biology covering less than 30 years: a period, however, that comprised the profound revolution in our thinking in genetics, biochemistry and ultrastructure which we now call molecular biology.

This period in Monod's work stretched over only 20 years: from the late 1940s, during which he wrote his first long classic review on 'enzymatic adaptation', published in Growth, to his Nobel prize article of 1966 . To get a proper perspective, it is illuminating to read these two articles directly in sequence. In the first, the problem was defined, the essential questions posed and some tentative, plausible mechanisms (often incorrect, but that is not the point) suggested. In the last, most, if not all, the questions had been answered.

In between, Monod had masterminded developments crucial to providing the answers. These include (amongst others) the discovery that specific inducers of enzyme formation are not necessarily even ligands of the enzyme, let alone substrates (1950); the illuminating application of the 'allometric plot' to the study of the kinetics of enzyme induction (1952); the demonstration (1954) that enzyme induction involved de novo biosynthesis of the specific enzyme protein from aminoacids; specific 'permeases' (195j); and the discovery (1958) that the inducer operated by antagonism of a specific gene-determined repressor. Thereafter followed the 'presentation' of a veritable avalanche of new concepts: 'structural' and 'regulatory' genes, the 'operator', the 'operon', the 'promoter', and finally (1962) the property of allostery which is of fundamental importance to the understanding of the control of enzyme function and enzyme synthesis.

In nearly all these developments Monod played a vital-usually a completely dominant-role. although it is important to realise that outstanding colleagues such as Mel Cohn and François Jacob (and indeed several others whom he guided and stimulated in his inimitable fashion) often also played an important-and sometimes essential -part; not forgetting André Lwoff himself who provided, right from the beginning, the emotional, intellectual and material background support without which almost everything would have been five times more difficult.

Monod's essential talent lay in his ability to combine a precise, logical formulation of a problem (that is, in terms that could be tackled experimentally and had meaning within the current 'paradigm') with an imaginative grasp of its implications in biology as a whole, and the power to initiate plausible interpretations yet move on from a concept, however attractive, once it was beginning to obstruct, rather than promote, the development of a subject. The difficulty, of course, is to recognise the obstruction. It is failure to do this that so often prevents research workers from making original discoveries. And nowhere is this better illustrated than in Monod's final rejec- 
tion of the cloying, but once attractive, hypothesis that the close similarity between the specificities of enzyme induction and enzyme function must mean that the mechanism of induction involves combination between the inducer and a receptor molecule consisting at least of a modified version of the enzyme, if not the enzyme itself. But the essential point to be grasped was that the relationship is functional, not chemical. Once Monod had discarded the false implications of the specificity similarities, he was free to postulate the true nature of the receptor, characterise and define the lac repressor and discover the phenomenon of allostery.

Thus, almost more than from the actual discoveries themselves, we can benefit from studying the way he used his mind. And that is one of the chief reasons why this collection of masterpieces is so valuable.

M. R. Pollock is Emeritus Professor of Biology at the University of Edinburgh, UK.

therapy and self-protection against the grim reality which surrounded him.

Accordingly, the main interest in the book is to be found in what may be called the strategies of dissent. Nowadays, it is taken for granted that any civil rights protest is essentially a demand that what is guaranteed by the constitution should be implemented in fact. Zhores Medvedev, the geneticist, for example, waged a major campaign against Soviet censorship on the grounds that "Secrecy of correspondence is guaranteed by law". Bukovsky relates how this procedure was first developed in the late 1960 s and how, when Alexander Yesenin-Volpin, the mathematician, first urged it, many budding dissidents were sceptical of its potential value-a scepticism which, as Bukovsky describes, has been refuted over and over again in the past decade.

Most fascinating, however, are the chapters dealing with Bukovsky's experiences of mental hospitals, for here we have the first-hand background to the reports which Bukovsky, in a brief spell of freedom, managed to transmit to the West. These reports for the first time drew attention to the new Soviet theory that political discontent equals mental disorder. Here too is the practical experience of psychiatric examinations and medical "commissions", which led Bukovsky, in collaboration with psychiatrist Semeon Gluzman, who is still serving a sevenyear sentence in a labour camp, to write their famous samizdat, Manual of Psychiatry for Dissidents. This is a slim but detailed handbook of how to behave under interrogation, with some pungent analyses of the main psychological types of interrogator likely to be encountered, and the best strategies for circumventing and frustrating them. In a book of the stature of $T o$ Build a Castle, it is regrettable that space could not have been found to include the 'Manual of Psychiatry' as an appendix - this is, however, one of the few faults one can find with an otherwise excellent work.

Vera Rich is Nature's regular correspondent on Soviet and East European affairs.

\section{FROM CHURCHILL LIVINGSTONE}

A major new textbook FUNCTIONAL HISTOLOGY A TEXT AND COLOUR ATLAS

Paul Wheater, George Burkitt, Victor Daniels and Philip Deakin

1979288 pages 387 colour, 83 black and white and 69 line illustrations paperback $£ 12.00$ / hardback $£ 20.00$

A unique and wholly intelligible picture of human/mammalian tissues.

To be published June, 1979

\section{HEMOSTASIS AND THROMBOSIS}

\section{A CONCEPTUAL APPROACH}

Jack Hirsh and Elizabeth Brain 1979110 pages line illustrations throughout paperback $£ 3.90$ Visually orientated, designed to accompany formal teaching, will foster an understanding of basic pathological and physiological concepts.

\section{THE BIOLOGY OF SENESCENCE}

Alex Comfort

\section{Third edition 416 pages} illustrated hardback 515.00

The only comprehensive work on mechanisms of ageing in man and other organisms.

\section{LABORATORY METHODS IN ANTIMICROBIAL CHEMOTHERAPY}

Edited by D.S. Reeves, I.Phillips, J.D.Williams and R. Wise

1978288 pages 17 half-tone +56 line illustrations hardback $\$ 15.00$ A comprehensive text, with the emphasis on practical techniques.

MEDICAL MICROBIOLOGY
VOLUME 1:
MICROBIAL INFECTIONS
Edited by J.P. Duguid,
B.P. Marmian and
R. H. A. Swain
1978 Thirteenth edition 680 pages
illustrated, including 30 colour plates
paperback f10.00 / hardback 14.00
Churchill Livingstone
23 Ravelston Terrace,
Edinburgh EH4 3TL, Scotland
through long years in prison and psychiatric ward, as a means of 